\title{
Comparison of Microbial Detection of Hemodialysis Water in Reasoner's 2A Agar (R2A) and Trypticase Soy Agar (TSA)
}

\author{
Sang-Hyun Park' ${ }^{1}$ Young-Hyeon Lee ${ }^{1}$, Min-Ho Yeo ${ }^{1}$, Hi-Ryun Lee ${ }^{1}$, Hye-Sook Kim² ${ }^{2}$ Kyung-Soo Chang ${ }^{1 *}$ \\ ${ }^{1}$ Department of Clinical Laboratory Science, Catholic University of Pusan, Busan 46252, Republic of Korea \\ ${ }^{2}$ Faculty of Pharmaceutical Sciences, Okayama University, Tsushima-Naka, Kita-Ku, Okayama 700-8530, Japan
}

\author{
Corresponding \\ Kyung-Soo Chang, Professor \\ Department of Clinical Laboratory \\ Science, Catholic University of Pusan, \\ Oryundae-ro 57, Geumjeong-gu, Busan \\ 46252, Republic of Korea \\ Phone : +82-51-510-0565 \\ Fax : +82-51-510-0568 \\ E-mail : kschang@cup.ac.kr
}

Received : May 24, 2021

Revised : June 28, 2021

Accepted : June 29, 2021

No potential conflict of interest relevant to this article was reported.

Copyright (C) 2021 Journal of Bacteriology and Virology

(C) This is an Open Access article distributed under the terms of the Creative Commons Attribution Non-Commercial License

(http://creativecommons.org/

license/by-nc/3.0/).
The quality management of dialysis water used as dialysis fluid is important for patients exposed to large amounts of water. The treatment of dialysis water causes chemical and microbiological contamination. Dialysis water contaminated with bacteria causes various diseases and inflammatory reactions due to the inflow of toxins into the body. Consequently, the aim of this study was to understand the sensitivity of agar for the detection of bacteria in dialysis water, the seasonal characteristics of bacterial culture, and bacterial identification. In all, 420 samples of dialysis water collected from a hospital between September 2017 and August 2018 were cultured at clinical laboratories. The bacterial growth rate of R2A was 99 cases $(23.5 \%)$, and that of TSA was 47 cases (11.1\%). R2A was more sensitive than TSA for samples incubated above $1 \mathrm{CFU} / \mathrm{ml}$ in hemodialysis, and TSA was more sensitive than R2A for samples incubated above $50 \mathrm{CFU} / \mathrm{ml}$. The morphological characteristics of the microorganisms were confirmed by gram staining 188 strains of 30 isolates from the specimens. In R2A, Gram-positive bacteria were isolated in 33.3\% $(n=42)$, Gram-negative bacteria were isolated in $56.3 \%(n=71)$, and fungal strains were isolated in $10.3 \%(n=13)$. In TSA, Gram-positive bacteria were isolated in $33.8 \%(n=21)$, Gram-negative bacteria were isolated in $64.5 \%(n=40)$, and fungal strains were isolated in $1.6 \%(n=$ 1). In addition, seasonal distinctions were observed in microbial cultures.

Key Words: Healthcare-associated infection, HAl, Hemodialysis water, R2A, TSA

\section{INTRODUCTION}

Healthcare-associated infection (HAl) includes nosocomial infections occurring in hospitals, out-of-hospital infections resulting from discharge, and outbreaks in the community (1). According to a study in the United States, HAl caused by multidrug-resistant bacteria infections occur in more than two million people each year. It was confirmed to account for $1 \%$ of all deaths (2). HAl includes surgical wound infections, bloodstream infections, urinary tract infections, and respiratory infections. Patients with significantly reduced immunity, such as the elderly, chronically ill, and organ transplant patients, are particularly vulnerable to HAI. Among the various treatments of patients, renal patients undergoing hemodialysis are treated with reduced immunity and are easily exposed to HAI, including injection needle accidents and multidrug-resistant bacteria, so infection control for hemodialysis is important $(3,4)$. According to the Korean Nephrological Association's 
Table 1. Maximum allowable levels of toxic chemicals and dialysis fluid electrolytes in dialysis water, Maximum allowable levels of trace elements in dialysis water ${ }^{*}$

\begin{tabular}{cccccc}
\hline Contaminant & $\begin{array}{c}\text { Maximum } \\
\text { Concentration } \\
(\mathrm{mg} / \mathrm{L})\end{array}$ & Contaminant & $\begin{array}{c}\text { Maximum } \\
\text { Concentration } \\
(\mathrm{mg} / \mathrm{L})\end{array}$ & Contaminant & $\begin{array}{c}\text { Maximum } \\
\text { Concentration } \\
(\mathrm{mg} / \mathrm{L})\end{array}$ \\
\hline Aluminum & 0.01 & Zinc & 0.1 & Beryllium & 0.0004 \\
Chloramines & 0.1 & Calcium & $2(0.1 \mathrm{mEg} / \mathrm{L})$ & Cadmium & 0.001 \\
Free Chlorine & 0.5 & Magnesium & $4(0.3 \mathrm{mEg} / \mathrm{L})$ & Chromium & 0.014 \\
Copper & 0.1 & Potassium & $8(0.2 \mathrm{mEg} / \mathrm{L})$ & Mercury & 0.0002 \\
Fluoride & 0.2 & Sodium & $70(3.0 \mathrm{mEg} / \mathrm{L})$ & Selenium & 0.09 \\
Lead & 0.005 & Antimony & 0.006 & Silver & 0.005 \\
Nitrate (as N) & 2 & Arsenic & 0.005 & Thallium & 0.002 \\
Sulfate & 100 & Barium & 0.1 & & \\
\hline
\end{tabular}

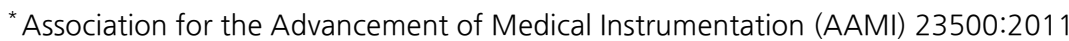

Table 2. Maximum allowable levels for total viable microbial count (TVC) and endotoxins in dialysis water *

\begin{tabular}{ccc}
\hline Contaminant & Maximum Allowable Level & Action Level \\
\hline TVC $^{+}$ & $<100 \mathrm{CFU} / \mathrm{ml}$ & $50 \mathrm{CFU} / \mathrm{ml}$ \\
endotoxins & $0.25 \mathrm{EU} / \mathrm{ml}$ & $0.125 \mathrm{EU} / \mathrm{ml}$ \\
\hline
\end{tabular}

${ }^{*}$ Association for the Advancement of Medical Instrumentation (AAMI) 23500:2011

${ }^{+}$TVC, Total Viable microbial Count

report "2018 Korea's Renal Replacement Therapy," the number of patients undergoing renal replacement therapy in Korea is 98,746 , of whom 73,059 are undergoing hemodialysis. In particular, the number of renal failure patients per one million population was reported as 1,907. The number of people with renal failure is increasing every year, and the mortality rate is high, so many academics and the media are interested. Chronic kidney disease is generally associated with old age, diabetes, hypertension, obesity, and cardiovascular disease, and hemodialysis is a major treatment for these kidney diseases (5). Most patients with CKD receive hemodialysis three times a week, and the dialysis regimen is targeted to eliminate about two-thirds of urea during each treatment (6). Waste products, such as urea, diffuse through a thin membrane that separates the dialysate flowing in the opposite direction from the blood. Most bacteria and viruses present in dialysate have a high molecular weight and cannot pass through a thin membrane. However, toxins and the like have a small molecular weight, so they can pass through the membrane, requiring special attention in the use of the dialysate (7). The quality management of dialysis water used as dialysate is important for patients exposed to large amounts of water (8). Abnormalities in the water purification facility of dialysis water cause chemical and microbiological contamination, and dialysis water contaminated with bacteria causes not only inflammatory reactions but also various diseases due to the influx of toxins into the body (9). Fever from bacterial infection is caused by bacterial inflammatory substances and stimulates the secretion of interleukin-1 (IL-1) and cytokines by peripheral blood mononuclear cells (PBMC) (10). IL-1 causes an increase in C-reactive protein (CRP), and cytokine mediates the host response to infection and is involved in acute and chronic inflammation of bacterial ions (11). Therefore, even if there is no sign of fever, increased cytokine production due to the contamination of dialysis water causes chronic inflammatory conditions, resulting in dialysis-related amyloidosis, hypoalbuminemia, atherosclerosis, hypotension, and coma (12). In medical institutions that perform dialysis, HAl should be prevented through the regular monitoring of dialysis water. Detailed guidelines for managing dialysis water are provided by organizations such as the Association for the Advancement of Medical Instrumentation (AAMI), the American National Standards Institute (ANSI), the International Organization for Standardization (ISO), and the European Best Practice Guidelines (EBPG). According to the AAMI guidelines (13), the quality control of dialysis water includes a chemical test (Table 1) to confirm the presence of heavy metals and a microbiological test (Table 2) to confirm the presence or absence 
of endotoxins and microorganisms. According to the AAMI guidelines, the acceptance criteria for dialysis water are less than $100 \mathrm{CFU} / \mathrm{ml}$ of bacteria and less than $0.25 \mathrm{EU} / \mathrm{ml}$ of endotoxins. In dialysis water, the action level (the concentration of bacterial contamination that must be taken before the maximum limit) is $50 \mathrm{CFU} / \mathrm{ml}$ of bacteria and $0.125 \mathrm{EU} / \mathrm{ml}$ of endotoxins, and corrective action must be taken quickly to drop below this level. As for the enforcement standards for each test, chemical tests should be conducted at least once a year, endotoxin tests must be conducted once a quarter, and microbial culture tests must be conducted once a month. For microbial culture tests, Trypticase Soy Agar (TSA) is recommended by the AAMI in the United States, and Reasoner's 2a Agar (R2A) is recommended by the International Organization for Standardization (ISO) (14). R2A and TSA studies reported that microbial cultures using R2A showed higher microbial detection compared to TSA cultures $(12,15)$. However, according to a study published in 2016 , there was no significant distinction in microbial cultures using TSA and R2A (16). Looking the above foreign cases, differences were confirmed in R2A and TSA. In addition, foreign research data did not include studies on environmental factors such as climate, season, and water quality in the country. In Korea, studies related to microbial culture tests and environmental factors for R2A and TSA in hemodialysis water are insufficient, and studies suitable for the domestic environment have been judged necessary to control infection and prevent HAI in hemodialysis water.

Therefore, this study aims to analyze the microbial culture and sensitivity of R2A, and TSA used in microbiological tests of hemodialysis water, identify seasonal microorganisms, and use them as basic data for improving hemodialysis infection control.

\section{MATERIALS AND METHODS}

\section{Study sample}

The hemodialysis water used in this study was a sample requested for microbial culture from September 2017 to August 2018, and 35 samples per month, a total of 420 samples were studied. According to the type of specimen, 396 cases of dialysis water and 24 cases of reverse osmosis water are classified.

\section{Sample Transport}

The samples were collected in a sterile, endotoxin-free container, and immediately transported to the laboratory for testing within 30 minutes.

\section{Inoculation Media}

Specimens requested from the laboratory were inoculated evenly on the surface of the medium by the spread plate method using a pipette in a TSA (Micromedia Co. Ltd., Korea) and an R2A (Asan Co. Ltd., Korea) medium, respectively. All tests were conducted in a biological safety cabinet (BSC class II), and the same specimen was repeated three times.

\section{Culture Methods}

As the culture media, TSA (Micromedia Co. Ltd., Korea) and R2A (Asan Co. Ltd., Korea) were selected, and an oxygen culture environment was selected as the culture condition. Regarding the incubation period, the TSA medium was cultured at $37^{\circ} \mathrm{C}$ for 48 hours, and the R2A medium was cultured at $27^{\circ} \mathrm{C}$ for one week (Table 3 ).

Table 3. Cultivation techniques in dialysis water

\begin{tabular}{|c|c|c|c|}
\hline Medium & Technique & Inoculation volume & Incubation Conditions \\
\hline TSA & Snread Plate & $10 \cap 0$ & $37^{\circ} \mathrm{C}, 48$ hour \\
\hline $\mathrm{R} 2 \mathrm{~A}$ & spread rlate & $1000 \mathrm{UL}$ & $27^{\circ} \mathrm{C}, 7$ days \\
\hline
\end{tabular}




\section{Gram Stain}

The pure cultured independent colonies were smeared on slides, dried, and stained according to the manufacturer's standard usage guidelines using a Gram stain reagent (YD Diagnostics Co. Ltd., Korea). The staining and morphological characteristics of the microorganisms were observed using a microscope $(\times 1,000)$. Microorganisms were identified by dividing them into gram-positive bacteria, gram-negative bacteria, and fungi through microscope checks.

\section{Statistical Analysis}

All experimental results were expressed as mean and standard deviation through a total of three experiments, and the statistical analysis tested for the mean value and significance using SPSS Version 25.0 for the window software program. The significance test was performed at the $p<0.05$ level.

\section{RESULTS}

\section{Comparing the number of dialysis water samples with bacterial culture by R2A and TSA}

Of the total 420 hemodialysis water samples, 28 cases (6.7\%) showed positive results for both R2A and TSA, and 71 cases (16.9\%) were positive for R2A and negative for TSA. There were 19 samples (4.5\%) that showed negative results in R2A and positive results in TSA, and 302 cases (71.9\%) were confirmed as negative results in both R2A and TSA (Table 4, Fig. 1).

\section{Comparison of the number of samples of dialysis water with bacterial positive cultures by} R2A and TSA

In confirming the positive rate of each medium in all samples, the microorganisms detected in R2A were higher than those detected in TSA, with 99 cases (23.5\%) in R2A and 47 cases (11.1\%) in TSA (Table 5).

Table 4. Comparing the number of dialysis water samples with bacterial culture by R2A and TSA

\begin{tabular}{|c|c|c|c|c|c|c|c|c|c|c|c|c|c|}
\hline & \multicolumn{13}{|c|}{ Number of samples } \\
\hline & Sep & Oct & Nov & Dec & Jan & Feb & Mar & Apr & May & Jun & Jul & Aug & $\begin{array}{l}\text { Total } \\
(\%)\end{array}$ \\
\hline$R_{P} T_{P}$ & 6 & 2 & 2 & 1 & 3 & 2 & 1 & 3 & 1 & 2 & 1 & 4 & $\begin{array}{c}28 \\
(6.7)\end{array}$ \\
\hline $\mathrm{R}_{\mathrm{P}} \mathrm{T}_{\mathrm{N}}$ & 8 & 8 & 4 & 3 & 14 & 2 & 3 & 3 & 13 & 2 & 6 & 5 & $\begin{array}{c}71 \\
(16.9)\end{array}$ \\
\hline $\mathrm{R}_{N} T_{\mathrm{P}}$ & 2 & 2 & 3 & 3 & 0 & 1 & 1 & 1 & 3 & 1 & 1 & 1 & $\begin{array}{c}19 \\
(4.5)\end{array}$ \\
\hline $\mathrm{R}_{N} T_{N}$ & 19 & 23 & 26 & 28 & 18 & 30 & 30 & 28 & 18 & 30 & 27 & 25 & $\begin{array}{c}302 \\
(71.9)\end{array}$ \\
\hline Total & 35 & 35 & 35 & 35 & 35 & 35 & 35 & 35 & 35 & 35 & 35 & 35 & $\begin{array}{c}420 \\
(100)\end{array}$ \\
\hline
\end{tabular}

$R_{P} T_{P}$, Positive growth on R2A and TSA

$R_{P} T_{N}$, Positive growth on R2A and No growth on TSA

$R_{N} T_{P}$, No growth on R2A and Positive growth on TSA

$R_{N} T_{N}$, No growth on R2A and TSA 


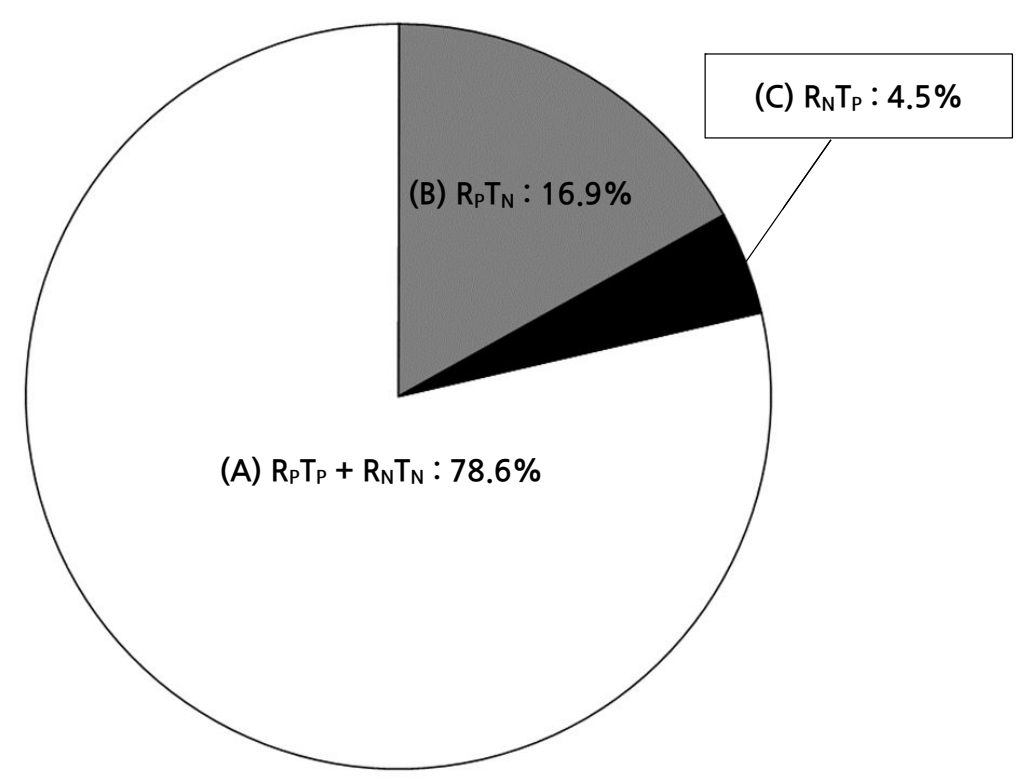

Fig. 1. Comparison of techniques for culturing dialysis water. (A) The positive growth of dialysis water and the negative growth of dialysis water were identified as 78.6\% in both R2A and TSA. (B) The positive growth on R2A and negative growth of TSA were identified as $16.9 \%$ in dialysis water. (C) The positive growth on TSA and negative growth of R2A were identified as $4.5 \%$ in dialysis water.

Table 5. Comparison of the number of samples of dialysis water with bacterial positive cultures by R2A and TSA

\begin{tabular}{cccccccccccccc}
\hline $\begin{array}{c}\text { Medium } \\
(\text { TN })^{*}\end{array}$ & Sep & Oct & Nov & Dec & Jan & Feb & Mar & Apr & May & Jun & $\begin{array}{c}\text { Jul } \\
\text { Aug }\end{array} \begin{array}{c}\text { Total } \\
(\%)\end{array}$ \\
\hline $\begin{array}{c}\text { R2A } \\
(420)\end{array}$ & 14 & 10 & 6 & 4 & 17 & 4 & 4 & 6 & 14 & 4 & 7 & 9 & $\begin{array}{c}9 \\
(23.5) \\
47\end{array}$ \\
$\begin{array}{c}\text { TSA } \\
(420)\end{array}$ & 8 & 4 & 5 & 4 & 3 & 3 & 2 & 4 & 4 & 3 & 2 & 5 & $(11.1)$ \\
\hline
\end{tabular}

* Total number of samples

Table 6. Comparison of bacteria growth on R2A and TSA media in identifying samples $\geq 50$ CFU/ml

\begin{tabular}{|c|c|c|c|c|c|c|c|c|c|c|c|c|c|}
\hline \multirow{2}{*}{$\begin{array}{l}\text { Medium } \\
(\mathrm{TN})^{*}\end{array}$} & \multicolumn{13}{|c|}{ Number of samples } \\
\hline & Sep & Oct & Nov & Dec & Jan & Feb & Mar & Apr & May & Jun & Jul & Aug & $\begin{array}{c}\text { Total } \\
(\%)\end{array}$ \\
\hline $\begin{array}{l}\text { R2A } \\
(420)\end{array}$ & 1 & 2 & 2 & 0 & 3 & 0 & 0 & 2 & 0 & 0 & 2 & 0 & $\begin{array}{c}12 \\
(2.8)\end{array}$ \\
\hline $\begin{array}{c}\text { TSA } \\
(420)\end{array}$ & 3 & 2 & 3 & 0 & 1 & 1 & 0 & 4 & 2 & 2 & 0 & 0 & $\begin{array}{c}18 \\
(4.2)\end{array}$ \\
\hline
\end{tabular}

* Total number of samples

\section{Comparison of bacteria growth on R2A and TSA media in identifying samples $\geq 50 \mathrm{CFU} / \mathrm{ml}$}

Among the 420 specimens, 12 (2.8\%) in R2A and 18 (4.2\%) in TSA were found to be cultured with more than 50 CFU/ml, and TSA was more sensitive than R2A (Table 6). 
Table 7. Comparison of bacteria growth on R2A and TSA media in identifying samples $<50$ CFU/ml

\begin{tabular}{ccccccccccccccc}
\hline $\begin{array}{c}\text { Medium } \\
(\text { TN })^{*}\end{array}$ & Sep & Oct & Nov & Dec & Jan & Feb & Mar & Apr & May & Jun & Jul & Aug & $\begin{array}{c}\text { Total } \\
(\%)\end{array}$ \\
\hline $\begin{array}{c}\text { R2A } \\
(420)\end{array}$ & 13 & 8 & 4 & 4 & 14 & 4 & 4 & 4 & 14 & 4 & 5 & 9 & $\begin{array}{c}87 \\
(20.7)\end{array}$ \\
$\begin{array}{c}\text { TSA } \\
(420)\end{array}$ & 5 & 2 & 2 & 4 & 2 & 2 & 2 & 0 & 2 & 1 & 2 & 5 & $\begin{array}{c}29 \\
(6.9)\end{array}$ \\
\hline
\end{tabular}

* Total number of samples

\section{Comparison of bacteria growth on R2A and TSA media in identifying samples $<50 \mathrm{CFU} / \mathrm{ml}$}

Among the 420 specimens, 87 (20.7\%) in R2A and 29 (6.9\%) in TSA were found to be cultured with less than 50 CFU/ml, and R2A was more sensitive than TSA (Table 7).

\section{Identification of heterotrophic bacteria isolated from dialysis water from September 2017} to August 2018

Of the 30 strains isolated from a total of 420 specimens, 188 strains were subcultured and studied. The isolated strains for each medium were identified as 126 in R2A and 62 in TSA, and the morphological characteristics of the microorganisms were confirmed through Gram staining.

In R2A, 42 Gram-positive strains (33.3\%), 71 Gram-negative strains (56.3\%), and yeast-like fungi accounted for 13 strains (10.3\%). In TSA, 21 Gram-positive strains (33.8\%), 40 Gram-negative strains (64.5\%), and yeast-like fungi accounted for one strain (1.6\%; Table 8$)$.

\section{Seasonal distribution of bacterial populations isolated from dialysis water}

The species of microorganisms separated from hemodialysis water were analyzed seasonally according to environmental factors, such as season and climate, in Korea (Table 9).

Seasonal comparison of the number of samples of dialysis water with bacterial positive culture by R2A and TSA

Because of the seasonal analysis of the one-year study, the positive cases of microorganisms isolated from R2A were confirmed to be 24 cases in spring, 19 cases in summer, 30 cases in autumn, and 26 cases in winter. The positive cases of microorganisms isolated from TSA were 10 cases in spring, nine cases in summer, 17 cases in autumn, and 11 cases in winter. It was confirmed that the positive rate of microorganisms cultured in R2A medium was higher in all four seasons than that of microorganisms cultivated in TSA, and a high positive rate was confirmed in autumn in both R2A and TSA mediums, showing characteristic results (Table 10).

\section{DISCUSSION}

The influx of microorganisms into the body is a risk factor that threatens human health by causing inflammatory reactions and various diseases. The rapid cultivation and identification of microorganisms is required for the treatment and prognosis 
Table 8. Identification of heterotrophic bacteria isolated from dialysis water from September 2017 to August 2018

\begin{tabular}{|c|c|c|c|}
\hline \multirow{2}{*}{ Gram stain } & \multirow{2}{*}{ Genus/Species } & \multicolumn{2}{|c|}{ Number of isolates } \\
\hline & & R2A & TSA \\
\hline \multirow[t]{12}{*}{ Gram Positive } & Staphylococcus epidermidis & 23 & 6 \\
\hline & Staphylococcus hominis & 6 & 2 \\
\hline & Kocuria rosea & 3 & 3 \\
\hline & Staphylococcus capitis & 2 & 3 \\
\hline & Staphylococcus warneri & - & 2 \\
\hline & Granulicatella elegans & - & 2 \\
\hline & Staphylococcus vitulinus & - & 1 \\
\hline & Globicatella sanguinis & - & 1 \\
\hline & Kocuria rhizophila & - & 1 \\
\hline & Micrococcus luteus & 7 & - \\
\hline & Kocuria kristinae & 1 & - \\
\hline & Total isolates & 42 & 21 \\
\hline \multirow[t]{19}{*}{ Gram Negative } & Sphingomonas paucimobilis & 27 & 9 \\
\hline & Acinetobacter /woffii & 12 & 3 \\
\hline & Oligella ureolytica & 10 & 7 \\
\hline & Roseomonas gilardii & 8 & 2 \\
\hline & Ralstonia pickettii & 7 & 1 \\
\hline & Burkholderia cepacia & 1 & 1 \\
\hline & Pantoea spp. & - & 4 \\
\hline & Achromobacter xylosoxidans & - & 4 \\
\hline & Delftia acidovorans & - & 1 \\
\hline & Bordetella bronchiseptica & - & 2 \\
\hline & Comamonas testosteroni & - & 2 \\
\hline & Aeromonas sobria & - & 1 \\
\hline & Aeromonas salmonicida & - & 1 \\
\hline & Moraxella spp. & - & 1 \\
\hline & Brucella spp. & - & 1 \\
\hline & Brevundimonas diminuta & 2 & - \\
\hline & Methylobacterium spp. & 2 & - \\
\hline & Cupriavidus pauculus & 2 & - \\
\hline & Total isolates & 71 & 40 \\
\hline Yeast like fungus & Candida sake & 13 & 1 \\
\hline
\end{tabular}

of diseases. Consequently, various media have been developed, and there have been changes in the culture environment and conditions. In particular, the selection of the medium is the most important factor in increasing the detection rate of microorganisms. In this study, microbiological tests of hemodialysis water were performed using R2A and TSA to confirm the positive rate for each medium, the positive rate for each season, and the results of microbial identification. This contributed greatly to the prevention of medical-related infections and the management of artificial kidney center infections implemented in medical institutions. It is the first in the world to reflect climate change and seasonal specificity, and it is a meaningful study conducted over a long time period. The positive rates of microorganisms in hemodialysis water were confirmed in 99 cases (23.5\%) in the R2A medium and 47 cases $(11.1 \%)$ in the TSA medium. Therefore, the R2A 
Table 9. Seasonal distribution of bacterial populations isolated from dialysis water

\begin{tabular}{|c|c|c|c|c|}
\hline Medium & Spring & Summer & Fall & Winter \\
\hline \multirow[t]{3}{*}{ R2A } & $\begin{array}{l}\text { Kocuria rosea } \\
\text { Staphylococcus } \\
\text { epidermidis }\end{array}$ & $\begin{array}{l}\text { Kocuria kristinae } \\
\text { Kocuria rosea } \\
\text { Micrococcus luteus }\end{array}$ & $\begin{array}{l}\text { Staphylococcus capitis } \\
\text { Staphylococcus } \\
\text { epidermidis } \\
\text { Staphylococcus hominis }\end{array}$ & $\begin{array}{l}\text { Staphylococcus } \\
\text { epidermidis } \\
\text { Staphylococcus hominis }\end{array}$ \\
\hline & $\begin{array}{l}\text { Acinetobacter Iwoffii } \\
\text { Burkholderia cepacia } \\
\text { Cupriavidus pauculus } \\
\text { Ralstonia pickettii } \\
\text { Sphingomonas } \\
\text { paucimobilis }\end{array}$ & $\begin{array}{l}\text { Staphylococcus capitis } \\
\text { Acinetobacter Iwoffii } \\
\text { Cupriavidus pauculus } \\
\text { Ralstonia pickettii } \\
\text { Sphingomonas } \\
\text { paucimobilis }\end{array}$ & $\begin{array}{l}\text { Acinetobacter lwoffii } \\
\text { Oligella ureolytica } \\
\text { Roseomonas gilardii } \\
\text { Sphingomonas } \\
\text { paucimobilis }\end{array}$ & $\begin{array}{l}\text { Acinetobacter lwoffii } \\
\text { Brevundimonas diminuta } \\
\text { Oligella ureolytica } \\
\text { Roseomonas gilardii } \\
\text { Ralstonia pickettii } \\
\text { Sphingomonas } \\
\text { paucimobilis }\end{array}$ \\
\hline & Candida sake & Candida sake & & \\
\hline \multirow[t]{2}{*}{ TSA } & $\begin{array}{l}\text { Staphylococcus capitis } \\
\text { Staphylococcus } \\
\text { epidermidis } \\
\text { Staphylococcus warneri }\end{array}$ & $\begin{array}{l}\text { Staphylococcus } \\
\text { epidermidis } \\
\text { Kocuria rhizophila }\end{array}$ & $\begin{array}{l}\text { Granulitella elegans } \\
\text { Kocuria rosea } \\
\text { Staphylococcus } \\
\text { epidermidis } \\
\text { Staphylococcus hominis } \\
\text { Staphylococcus vitulinus } \\
\text { Staphylococcus warneri }\end{array}$ & $\begin{array}{l}\text { Globicatella sanguinis } \\
\text { Kocuria rosea } \\
\text { Staphylococcus capitis }\end{array}$ \\
\hline & $\begin{array}{l}\text { Achromobacter } \\
\text { xylosoxidans } \\
\text { Aeromonas salmonicida } \\
\text { Burkholderia cepacia } \\
\text { Moraxella spp. } \\
\text { Ralstonia pickettii } \\
\text { Sphingomonas } \\
\text { paucimobilis }\end{array}$ & $\begin{array}{l}\text { Acinetobacter lwoffii } \\
\text { Bordetella bronchiseptica } \\
\text { Comamonas testosteroni } \\
\text { Sphingomonas } \\
\text { paucimobilis, }\end{array}$ & $\begin{array}{l}\text { Achromobacter } \\
\text { xylosoxidans } \\
\text { Brucella spp. } \\
\text { Oligella ureolytica } \\
\text { Pantoea spp. } \\
\text { Roseomonas gilardii } \\
\text { Sphingomonas } \\
\text { paucimobilis }\end{array}$ & $\begin{array}{l}\text { Acinetobacter /woffii } \\
\text { Aeromonas sobria } \\
\text { Delftia acidovorans } \\
\text { Oligella ureolytica }\end{array}$ \\
\hline
\end{tabular}

Table 10. Seasonal comparison of the number of samples of dialysis water with bacterial positive culture by R2A and TSA

\begin{tabular}{cccccc}
\hline $\begin{array}{c}\text { Medium } \\
\text { (Total No. } \\
\text { of samples) }\end{array}$ & Spring & Summer & Fall & Winter & $\begin{array}{c}\text { Total } \\
(\%)\end{array}$ \\
\cline { 2 - 6 } R2A & 24 & 19 & 30 & 26 & 99 \\
$(420)$ & 10 & 9 & 17 & 11 & $(23.5)$ \\
TSA & 10 & & & 47 \\
$(420)$ & & & & & $(11.1)$ \\
\hline
\end{tabular}

medium was found to be more sensitive than the TSA medium. In the Netherlands (15), in a study conducted on 229 samples of hemodialysis water and reverse osmosis water, the R2A medium showed a higher positive rate than the TSA medium, confirming results similar to this study. In Thailand (12), a study conducted on 143 samples of reverse osmosis water, also confirmed that the R2A medium was more sensitive than the TSA medium. The positive rate of bacteria counts of $50 \mathrm{CFU} / \mathrm{mL}$ or higher was found to be $2.8 \%$ in R2A and $4.2 \%$ in TSA in this study, which was higher than that of $1.5 \%$ in R2A and $1.3 \%$ in TSA, the results of the US study. When comparing the results with those of advanced countries, it is thought that a more active management of hemodialysis water is necessary. R2A is a low-nutrient agar used with lower incubation temperatures and longer incubation times (17). However, TSA is a universal medium containing two peptones to support the growth of various microorganisms (18). Hence, the identification and positive rates of microorganisms 
cultured in the two media are considered different. The 188 strains of 30 species isolated in this study were classified into 33.5\% Gram-positive microorganisms, 59.0\% Gram-negative microorganisms, and 7.4\% yeast-like fungi. Aeromonas sp., rarely cultured in TSA, is a bacterium that exists in fresh water and has been reported as a zoonotic pathogen that causes corneal inflammation in a recent domestic study (19). Moraxella sp. is also known as the causative agent of infectious diseases of otolaryngology (20). In Japan, bloodstream infections caused by Methylobacterium sp. have been reported in patients undergoing hemodialysis (21). Especially Sphingomonas paucimobilis, Acinetobacter Iwoffii, and Oligella ureolytica showed high separation rates among Gram-negative microorganisms. In a Thai study, Pseudomonas spp. was 40\%, Moraxella spp. 23\%, Acinetobacter spp. 16\%, Staphylococcus spp. 16\%, Alcaligenase spp. 14\%, Gram-negative rod 7\%, Corynebacterium spp. 3\%, Micrococcus spp. 3\%, Bacillus spp. 1\%, Chromobacterium spp. 1\%, Gram-positive rod $1 \%$, Rhodococcus spp. $1 \%$, and Streptococcus spp. $1 \%$ was isolated, which was like this study in that the separation rate of Gram-negative microorganisms was high (12). The species of microorganisms isolated from hemodialysis water differed from season to season, and Acinetobacter Iwoffii and Sphingomonas paucimobilis were identified as bacteria isolated throughout the year from R2A. Sphingomonas paucimobilis is an opportunistic pathogen that causes meningitis, sepsis, bacteremia, and peritonitis in people with reduced immunity (22). Acinetobacter /woffii is a potential opportunistic pathogen in patients with impaired immune systems, and it has been identified as a cause of healthcare-associated infections (23). It is necessary to manage infections more effectively for hemodialysis water by monitoring bacteria that are separated year-round and bacteria that are separated by season. In foreign countries, there have been no studies on the detection of microorganisms in hemodialysis water related to season or climate. However, in Korea, the four seasons are distinct, and the temperature change varies greatly from season to season. The cultivation of microorganisms is closely related to the temperature and growth of bacteria, as well as the components of the medium and cultivation time. Therefore, if the R2A medium and the TSA medium are used together for the microbiological testing of hemodialysis water, it is believed that they can contribute to patient safety and public health safety infections.

\section{REFERENCES}

1) Yoo JH. Principle and perspective of healthcare-associated infection control. J Korean Med Assoc 2018:61:5-12.

2) Evans CT, Jump RL, Krein SL, Bradley SF, Crnich, CJ, Gupta K, et al. Setting a Research Agenda in Prevention of Healthcare-Associated Infections (HAls) and Multidrug-Resistant Organisms (MDROs) Outside of Acute Care Settings. Infect Control Hosp Epidemio/ 2018;39:210-3.

3) Choi JS. Infection control for hemodialysis and endoscopy unit. Hanyang Medical Reviews 2011:31:167-76.

4) Vincenti S, Quaranta G, De Meo C, Bruno S, Ficarra MG, Carovillano S, et al. Non-fermentative gram-negative bacteria in hospital tap water and water used for haemodialysis and bronchoscope flushing: prevalence and distribution of antibiotic resistant strains. Sci Total Environ 2014;499:47-54.

5) Levey AS, Coresh J. Chronic kidney disease. Lancet 2012;379:165-80.

6) Sirich TL, Funk BA, Plummer NS, Hostetter TH, Meyer TW. Prominent accumulation in hemodialysis patients of solutes normally cleared by tubular secretion. J Am So Nephro/2014;25:615-22.

7) Canaud B, Morena M, Leray-Moragues H, Chalabi L, CRISTO JP. Overview of clinical studies in hemodiafiltration: what do we need now? Hemodial Int 2006;10:S5-S12.

8) Chen L, Zhu X, Zhang M, Wang Y, Lv T, Zhang S, et al. Profiling Total Viable Bacteria in a Hemodialysis Water Treatment System. J Microbiol Biotechno/2017:27:995-1004.

9) Lonnemann G, Krautzig S, Koch KM. Quality of water and dialysate in haemodialysis. Nephrol Dial Transplant 1996:11:946-9. 
10) Lonnemann G, Behme TC, Lenzner B, Floege J, Schulze M, Colton CK, et al. Permeability of dialyzer membranes to TNF $\alpha$-inducing substances derived from water bacteria. Kidney Int 1992:42:61-8.

11) Dinarello CA. 1992. Interleukin-1 and tumor necrosis factor: effector cytokines in autoimmune diseases. Semin Immuno/ 1992:4:133-45.

12) Punakabutra N, Nunthapisud P, Pisitkun T, Tiranathanagul K, Tungsanga K, Eiam-Ong S. Comparison of different culture methods on bacterial recovery in hemodialysis fluids. J Med Assoc Thai 2004;87:1361-7.

13) Association for the Advancement of Medical Instrumentation. ANSI/AAMI/ISO 23500: 2011 Guidance for the preparation and quality management of fluids for hemodialysis and related therapies. Arlington VA: 2011. P.9-30.

14) Reasoner DJ. Heterotrophic plate count methodology in the United States. Int J Food Microbio/2004;92:307-15.

15) Van der Linde K, Lim BT, Rondeel JM, Antonissen LP, de Jong GM. Improved bacteriological surveillance of haemodialysis fluids: a comparison between Tryptic soy agar and Reasoner's 2A media. Nephrol Dial Transplant 1999:14:2433-7.

16) Maltais JAB, Meyer KB, Foster MC. Comparison of techniques for culture of dialysis water and fluid. Hemodial Int 2017:21:197-205.

17) Reasoner DJ, Geldreich EE. A new medium for the enumeration and subculture of bacteria from potable water. App/ Environ Microbio/ 1985:49:1-7.

18) Alsammarraie FK, Wang W, Zhou P, Mustapha A, Lin M. Green synthesis of silver nanoparticles using turmeric extracts and investigation of their antibacterial activities. Colloids Surf B Biointerfaces 2018;171:398-405.

19) Kim Y, Shin HB, Lee SH. Radial Keratoneuritis in Aeromonas Keratitis. J Korean Ophthalmo/ Soc 2019;60:792-6.

20) Fokkens WJ, Lund VJ, Mullol J, Bachert C, Alobid I, Baroody F, et al. EPOS 2012: European position paper on rhinosinusitis and nasal polyps 2012. A summary for otorhinolaryngologists. Rhinology 2012:50:1-12.

21) Kaneko M, Tominaga $Y$, Sakamoto $K$, Shikata $H$. Hemodialysis vascular access infection caused by Methylobacterium radiotolerans: the first confirmed case in Japan. J Infect Chemother 2020;26:107-9.

22) Ryan MP, Adley CC. Sphingomonas paucimobilis: a persistent Gram-negative nosocomial infectious organism. J Hosp Infect 2010;75:153-7.

23) Bergogne-Bérézin E, Towner KJ. Acinetobacter spp. as nosocomial pathogens: microbiological, clinical, and epidemiological features. Clin Microbiol Rev 1996;9:148-65. 